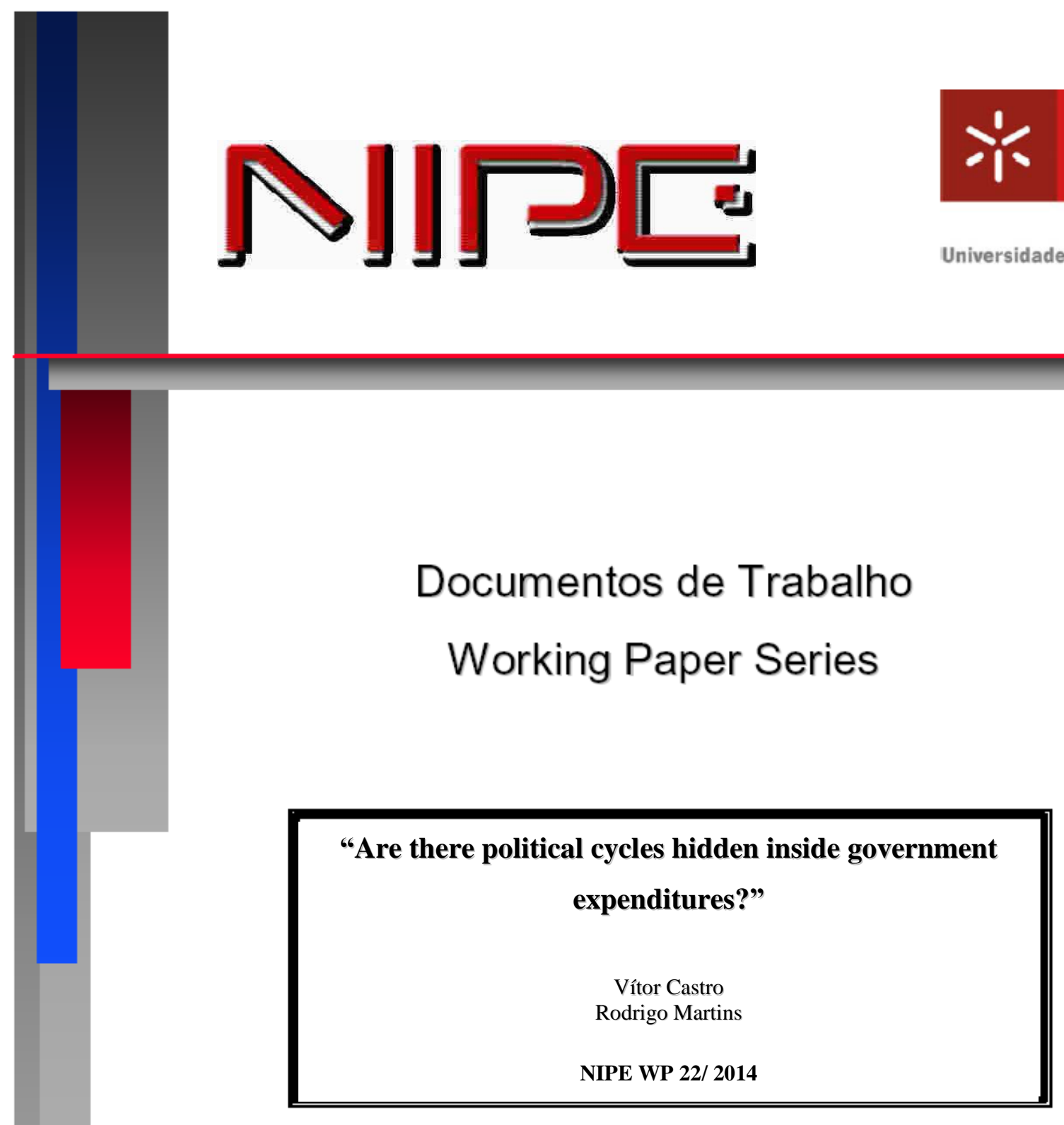

NÚCLEO DE INVESTIGAÇÃO EM POLÍTICAS ECONÓMICAS UNIVERSIDADE DO MINHO 
"Are there political cycles hidden inside government

expenditures?"

Vítor Castro

Rodrigo Martins

NIPE* WP 22/ 2014

URL:

http://www.eeg.uminho.pt/economia/nipe
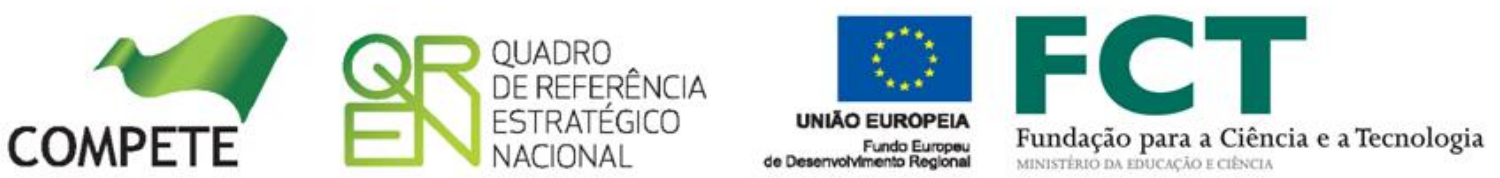


\title{
Are there political cycles hidden inside government expenditures?*
}

\author{
Vítor Castro ${ }^{\mathrm{a}}$ \\ ${ }^{a}$ Faculty of Economics, University of Coimbra, Portugal \\ and Economic Policies Research Unit (NIPE), Portugal \\ Rodrigo Martins ${ }^{\mathrm{b}, \boldsymbol{*}}$ \\ ${ }^{b}$ Faculty of Economics, University of Coimbra, Portugal \\ and Group for Monetary and Fiscal Studies (GEMF), Portugal
}

November 2014

\begin{abstract}
This paper examines the presence of political cycles inside the Portuguese governments' aggregate expenditures by using annual data for 10 expenditure components. The results indicate that the choice of the expenditure components to be increased during election periods by Portuguese governments generally relates to more visible items such as general public services, social protection and health care.
\end{abstract}

Keywords: Political Budget Cycles; Portugal; Elections; Fiscal Policy. JEL classification: H72, D72, D78.

\footnotetext{
* The authors acknowledge helpful comments and suggestions from the participants at the NIPE's Seminar, University of Minho, Portugal, 22 January 2014; the 2014 Meeting of the European Public Choice Society, University of Cambridge, UK, 3-6April 2014; and the $8^{\text {th }}$ Annual Meeting of the Portuguese Economic Journal, University of Minho, 4-5 July 2014. The authors also thank the financial support provided by the Portuguese Foundation for Science and Technology under research grant PEst-C/EGE/UI3182/2011 (partially funded by COMPTE, QREN and FEDER).

* Corresponding author. Address: Faculty of Economics, University of Coimbra, Av. Dias da Silva 165, 3004-512 Coimbra, Portugal. Tel.: +351 239 790578; Fax: +351 239 790514; E-mail: rodrigom@fe.uc.pt
}

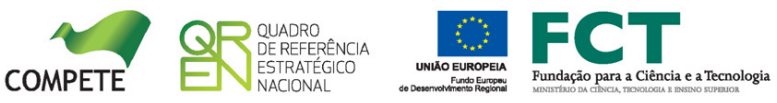




\section{Introduction}

This paper investigates the presence of political budget cycles in the Portuguese fiscal policy at a disaggregated level. Policy makers in democracies have clear incentives to use economic policies to their own advantage. Therefore, the influence of electoral concerns and government ideology on short-term economic performance has been an important topic in Public Choice. Empirics has consistently shown evidence of periodical shifts in economic aggregates associated with political motives, although mixed results are found regarding the partisan or opportunistic nature of these cycles.

This article focuses on the particular case of government spending in Portugal. We know that the Stability and Growth Pact constrains EU members' fiscal policy, however not much else really remains to maneuver before elections and, in reality, some studies have found evidence that, although constrained, fiscal policy exhibits political motives. However, Portuguese reality is under-researched especially at the national level and constitutes an excellent testing ground to examine Brender and Drazen's (2005) claim that political budget cycles are a phenomena of new democracies. Furthermore, in recent years we have witnessed a renewed interest on the understanding of fiscal policy determinants and outcomes, more so in the case of a country like Portugal that since the turn of the decade is experiencing budgetary control difficulties.

Instead of the traditional analyses of the main aggregates related to fiscal policy, we want to dig deeper and investigate political motives in the composition of government expenditures. For such a task, we use a dataset of annual data for ten main areas of government spending in Portugal.

The results presented by this study are quite interesting, providing dissimilar preferences over different expenditure components. Independently of its ideology, 
governments usually choose to increase those expenditure components that have more visibility and impact in terms of electoral return: general public services, social protection and health care.

The article is organized as follows. Section 2 provides a brief review of the literature. Section 3 describes the data and the econometric models to be used in the empirical analysis. The empirical results are presented and discussed in section 4 and section 5 concludes.

\section{Review of the literature}

The seminal work of Downs (1957) emphasizes the idea that economic strategies are not politically harmless nor political choices are free of economic concerns. To better understand this relationship numerous scholars have tried to comprehend how the ideological preferences of governments, the electoral agenda, and the competition between parties affect macroeconomic variables. Two main theories emerge from the literature: the political business cycle approach (Nordhaus, 1975) and the partisan theory (Hibbs, 1977). The first assumes that politicians have no policy preferences, so they act "opportunistically" selecting the policies that maximize their electoral support. They create unusual favorable economic conditions before an election and - in order to correct this artificial unbalance - contractionary measures are implemented immediately after the elections. Alternatively, the partisan theory does not view politicians as homogenous, arguing that different parties have different policy objectives, behaving, when in office, in a partisan manner. ${ }^{1}$ Specifically, left-wing parties are relatively more concerned with

\footnotetext{
${ }^{1}$ The partisan model generates policy effects after elections, while the opportunist model generates policy effects before elections.
} 
unemployment (growth) than with inflation, whereas right-wing parties are especially worried with inflation control.

In the 1980's and 1990's rational versions of both theories emerged, exploring the assumption that voters form expectations rationally. In a context where competence and asymmetric information are the key elements, both rational partisan models (Alesina, 1987; Alesina and Sachs, 1988) and rational opportunistic models (Rogoff and Sibert, 1988; Rogoff, 1990) resulted in the reduction of policymaker's ability to induce political cycles.

Empirical studies suggest that favorable economic conditions benefit governments (Hibbs, 2006). Partisan behavior seems to be more frequent in developed countries (Alesina and Roubini, 1992; Alesina et al., 1997), while opportunistic behavior appears to gather more support in developing countries (see, for instance, Brender and Drazen, 2009; Vergne, 2009; and Shi and Svensson, 2006).

Along with the other main economic aggregates, governments' fiscal policy has also been studied to check if it is governed by political as much as economic considerations. The extension of the traditional approaches to fiscal policy is straightforward: boosts in expenditures and/or revenue reductions prior to elections should signal opportunistic behavior, while in the partisan perspective left-wing governments are more prone to budget deficits than their counterparts. The actual modeling of political budgetary cycles came with Rogoff and Sibert's (1988) work that presented a model of adverse selection underlining competence and asymmetric information. A further refinement made by Rogoff (1990) highlighted the need to search budgetary cycles inside the broad aggregates, especially in the composition of government spending. The model considers that the most efficient way for governments to signal 
competence is to divert spending from capital spending to current spending thus favoring transfers and more visible programs. The idea is to increase those expenditures that send the strongest signals, consequently trading those that generate benefits over time for those that are noticeable immediately.

Several studies, both at national and multi-national level, have provided evidence of the relationship between elections and fiscal policy manipulations. Shi and Svensson (2002a, b; 2006), using multi-country data, consistently capture political budget cycles and show that the effect is significantly stronger in less developed countries. In their latter article they find that, on average, fiscal deficits increases by $22 \%$ in election years. For a set of developed countries, Persson and Tabellini (2003) find a political revenue cycle, but no trace of political cycle in expenditures, budget or transfers. Focusing on EU countries Andrikopoulos et al. (2004) do not find a fiscal electoral cycle, Mink and de Haan (2006) report a budget deficit increase in electoral years and a significant but small partisan effect on fiscal aggregates, while Efthyvoulou (2012) concludes that governments across the EU tend to generate budgetary opportunistic cycles and that these are much larger in the Eurozone countries. Highlighting institutional features, Persson and Tabellini (2002) show that the form of government (presidential or parliamentary) and the electoral rules (proportional or majoritarian) affect the configuration of budget cycles.

Other studies explore the expenditure components. Alesina (1988), for example, reports a small electoral cycle in transfers in the United States. For Canada, the results found by Blais and Nadeau (1992) suggest a short pre-electoral cycle observable on road expenditures and social services, while Potrafke (2010), focusing on direct transfer payments, finds that incumbents increase the growth of public health expenditures in election years. 
For Portugal there is some relevant research done but restricted to the local governments' political budget cycle. For example, Veiga and Veiga (2007a) report an increase in local governments' total expenditures before elections and a change in their composition that favors items immediately visible to the electorate, namely investment expenditures on overpasses, streets and complementary works, and on rural roads. ${ }^{2}$ One of the main objectives of the present article is to check if this behavior of local authorities is also present at the national level of Portuguese governance.

\section{Data and econometric model}

In order to investigate potential politically-driven changes in the composition of expenditures, we use a panel of annual data for 10 components of the Portuguese government expenditures, as defined by the OECD, over the period 1990-2011. According to the classification of governments' functions (COFOG), regarded by the OECD as the appropriate basis to examine the structure of government expenditure, there are ten components to be considered: general public services; defence; public order and safety; economic affairs, environmental protection, housing and community amenities; health; recreation, culture and religion; education; and social protection (see Table A.1 for more details). Although each component could be estimated separately as a time series, we opted to organize the components in a panel due to the data's limited time span and to take advantage of the increased number of observations when testing.

We employ the following empirical model to test opportunistic and partisan effects on the components of government expenditures:

\footnotetext{
${ }^{2}$ Also at local level, Veiga and Pinho (2007) analyze the political determinants related to the allocation of intergovernmental grants and Veiga and Veiga (2007b) find that there is an electoral payoff to opportunistic investment expenditures.
} 


$$
\Delta \operatorname{CompExpd}_{i t}=\alpha+\gamma \Delta \operatorname{CompExpd}_{i t-1}+\lambda \operatorname{DPol}_{t} \text { Comp }_{i}+\eta_{i}+u_{i_{t}}
$$

where $i=1, \ldots, 10, t=1991, \ldots, 2011$. The dependent variable is the change in the respective expenditures component as percentage of the total expenditures; ${ }^{3}$ Comp $_{i}$ is a dummy variable that takes the value of 1 for component $i$ of the government expenditures and $D P o l$ controls for political cycles: when estimating opportunistic effects takes the value 1 in the electoral year (and 0, otherwise), and when estimating partisan effects takes the value of 1 for left-wing governments (and 0 , otherwise). As the sum of all shares of the components to the government total expenditures is equal to 1 , one of the expenditure components has to be excluded from the regression analysis. ${ }^{4}$

In dynamic estimations the fixed effects estimator is biased. The estimators that take into account that bias can be grouped into: the instrumental variables estimators; and bias-corrected estimators. According to the large sample properties of the GMM methods, the dynamic estimator proposed by Arellano and Bond (1991) will also be biased if employed to our specification given that we only have 10 individual-components in the dataset and a number of time periods significantly larger. Hence, a bias-corrected estimator is more appropriated here. Therefore, we apply Bruno's (2005a, 2005b) biascorrected least squares dummy variable estimator for dynamic panel data models with small N. The Blundell and Bond (1998) estimator is used as the initial estimator where the instruments are collapsed as suggested by Roodman (2009), which avoids using invalid or

\footnotetext{
${ }^{3}$ All variables are defined in Table A.2 and the respective descriptive statistics can be found in Table A.3. The first difference of the dependent variable is used because the panel unit root tests are not clear regarding its stationarity in level. The Fisher unit root tests based on the Phillips-Perron tests do not reject the null hypothesis that "all panels contain unit roots" for the CompExpd variable, but reject it when its first difference is considered (see Table A.4 in Annex). Therefore, $\Delta$ CompExpd is used as dependent variable. ${ }^{4}$ This issue will be clarified below in the analysis of the empirical results.
} 
too many instruments. We undertake 25 repetitions of the procedure to bootstrap the estimated standard errors. ${ }^{5}$

\section{Empirical results}

As the time span is relatively small, instead of the traditional time series analyses, a dynamic panel data model is employed to detect on which components Portuguese governments tend to act politically. We start by leaving the component "defence" out of the estimations and considering social protection as the baseline category for comparisons. Hence, all but one of the remaining nine multiplicative dummies are included in the model. The results are shown in Table 1.

\section{[Insert Table 1 around here]}

Our findings indicate that expenditures on general public services tend to increase in election years at the expenses of social protection; a similar effect is found for health expenditures, but expenditures in economic affairs present a substantial decrease in election years (see column 1 in Table 3). The other components of expenditures do not change significantly relatively to social protection. The results are very similar when we leave the dummy for environmental protection out instead of defence (see column 2). We also checked for partisan effects in the components of the expenditures (see column 3), but no relevant results were found. ${ }^{6}$

Next, we explore whether the dynamics of those components is influenced or not by the elections and ideology (columns 4 and 5). The dependent variable is replaced by

\footnotetext{
${ }^{5}$ The results do not qualitatively change with more repetitions (50, 100 or 200) or when the Arellano and Bond (1991) estimator is chosen as initial estimator. Those results are available upon request.

${ }^{6}$ In this case, the variable DPol takes the value of 1 when a left-wing government is in office and 0 otherwise.
} 
the growth rate of the components $($ GrExpd $) .{ }^{7}$ Regarding the election effects, we observe that the growth rate of expenditures on defence, public order and safety, economic affairs and housing, and community amenities decreases substantially during election years in comparison with social protection. The results seem to confirm for some cases the idea of increases in those expenditures that are related to items more immediately visible to voters. The findings on the partisan side remain weak: only housing and community amenities seem to present a higher growth rate in comparison to social protection when a left-wing party is in office.

Concerning this evidence, we conclude that the opportunistic effects are much more relevant than the partisan effects when we focus our analysis on the components of public expenditures. The panel data framework used allows us to more clearly understand the potential electoral differences between the components, by enabling the construction of a matrix where the estimated impact of each component is compared with all the others. To construct that matrix we depart from regression 1 in Table 3, leaving outside one component at a time and considering different basis categories in order to collect all the possible effects between the ten expenditure components considered in this study. The results of that extensive analysis are reported in Table 4 and compare each component (first column) with the respective basis-category (in line).

\section{[Insert Table 2 around here]}

The results present some interesting patterns. Noticeably, the biggest losers in election years are defence and economic affairs. While the results for the first were expected, we had no prior expectations regarding the second manly due to the mix between strong/weak signalling and short/long term characteristics found in the

\footnotetext{
${ }^{7}$ As here the sum of the growth rates do not adds up to 1 or $100 \%$, we do not need to exclude any category from the estimations, but we keep social protection as the basis category.
} 
aggregate's composition. Expenditures on economic affairs seem to be penalized relatively to health, environmental protection, recreation, education and social protection.

As to the components preferred in election years clearly public services and also health and social protection seem to stand out. In election years the percentage of general public services to the total of public expenditures increases when compared with all the other components, except with health. Expenditures on health also tend to increase in the election years relatively to defence, public order and safety, economic affairs and social protection. These components exhibit strong signalling characteristics and can provide electoral effects in the short-run. The results are in line with previous findings (see, for instance, Blais and Nadeau, 1992and Potrafke, 2010). Possibly one of the reasons for public services to be so highlighted in election years is because it includes general transfers between different levels of the governmental structure. Those transfers probably increase in order to conclude constructions or are used on other highly visible items. In fact, Veiga and Pinho (2007) found evidence that political factors exert an important role in the distribution process of intergovernmental grants at Portuguese local elections.

\section{Conclusions}

In this paper we analyse whether the components of public expenditures in Portugal exhibit politically driven cycles. The empirical analyses reveal that opportunist effects on the expenditure components are significantly more important than partisan effects. In general, the way Portuguese governments are found to "play" with expenditure components is consistent with previous studies and theoretical expectations. In particular, the results show that governments, independently of its ideology, usually choose to 
increase those expenditure components that have more visibility and impact in terms of electoral return: general public services, social protection and health care. Therefore, we conclude that Portuguese governments tend to act opportunistically in election years by favouring those components that can provide them with the best chances of winning the elections.

\section{References}

Alesina, A., 1987. Macroeconomic Policy in a Two-Party System as a Repeated Game. Quarterly Journal of Economics, 1023, 651-78.

Alesina, A., Sachs, J., 1988. Political Parties and Business Cycle in the United States, 1948-84. Journal of Money, Credit, and Banking, 201, 63-82.

Alesina A., 1988. Macroeconomics and politics. Nat. Bur. Econ. Res. Macroeconomics Annual. $3: 13-61$.

Alesina A, Cohen, G, Roubini, N., 1992. Macroeconomic policies and elections in OECD democracies. Economics \& Politics.,41, 1-30

Alesina, A., Cohen, G., Roubini, N., 1997. Political Cycles and the Macroeconomy. Cambridge, Mass. and London, The MIT Press.

Arellano, M., Bond, S., 1991. Some Tests of Specification for Panel Data: Monte Carlo Evidence and an Application to Employment Equations. Review of Economic Studies, 58, 277-297.

Blais, A., Nadeau, R., 1992. The Electoral Budget Cycle. Public Choice, 744, 389-403.

Blundell, R., Bond, S., 1998. Initial Conditions and Moment Conditions in Dynamic Panel Data Models. Journal of Econometrics, 87, 115-143. 
Brender, A., Drazen, A., 2005. Political budget cycles in new versus established democracies. Journal of Monetary Economics, 52(7), 1271-1295.

Brender, A., Drazen, A., 2009. How do budget deficits and economic growth affect Reelection prospects? Evidence from a large panel of countries. American Economic Review. 98, 2203-2220.

Bruno, G., 2005a. Estimation and inference in dynamic unbalanced panel-data models with a small number of individuals. Stata Journal, 5(4), 473-500.

Bruno, G., 2005b. Approximating the bias of the LSDV estimator for dynamic unbalanced panel data models. Economics Letters, 87(3), 361-366.

Efthyvoulou, G., 2012. Political budget cycles in the European Union and the impact of political pressures. Public Choice, 153, 295-327.

Frey, B., Schneider, F., 1978. An Empirical Study of Politico-Economic Interactions in theUnited States.Review of Economic and Statistics, 59, 663-688.

Hibbs, D., 1977. Political Parties and Macroeconomic Policy. American Political Science Review. $71,1467-87$.

Hibbs, D., 2006. Voting and the Macroeconomy. In B. R. Weingast \& D. A. Wittman Eds., The Oxford handbook of political economy pp. 565-586. Oxford: Oxford University Press.

Mink, M., De Haan, J.,2006, Are There PoliticalBudget Cycles in the Euro Area? European UnionPolitics, 7, 191-211.

Nordhaus, W. D., 1975. The Political Business Cycle. Review of Economic Studies, XLII2, 169-190.

Persson, T., Tabellini, G., 2002. Do electoral cycles differ across political systems?Working Paper No.232. IGIER, Bocconi University.

Persson, T., Tabellini, G., 2003. The Economic Effect of Constitutions: What do the Data Say? MIT Press, Cambridge, MA. 
Potrafke, N., 2010. The growth of public health expenditures: do government ideology and electoral motives matter? Journal of Health Economics,296, 797-810.

Roodman, D., 2009. How to do xtabond2: An introduction to difference and system GMM in Stata. Stata Journal, 9(1), 86-136.

Rogoff, K., 1990. Equilibrium Political Budget Cycles. The American Economic Review. 801, 21-36.

Rogoff, K., Sibert, A., 1988. Elections and Macroeconomic Policy Cycles. Review of Economic Studies. LV1, 1-16.

Shi, M., Svensson, J., 2002a. Conditional political budget cycles. CEPR Discussion Paper \#3352.

Shi, M., Svensson, J., 2002b. Political business cycles in developed and developing countries, working paper, IIES, Stockholm University.

Shi, M., Svensson, J.,2006. Political budget cycles: Do they differ across countries and why? Journal of Public Economics, 90, 1367-1389.

Veiga, F J., Veiga, L., 2007a. Political business cycles at municipal level. Public Choice, 131 (1-2), 45-64.

Veiga, F J., Veiga, L., 2007b. Does opportunism pay off? Economics Letters, 96, 177-182.

Veiga, L., Pinho, M., 2007. The political economy of intergovernmental grants: Evidence from a maturing democracy. Public Choice, 133, 457-477. 


\section{List of Tables}

Table 1. Empirical results for the decomposition of the government expenditures

\begin{tabular}{|c|c|c|c|c|c|}
\hline & Elect & Elect & LeftGov & Elect & LeftGov \\
\hline & (1) & (2) & (3) & (4) & (5) \\
\hline \multirow[t]{2}{*}{$\Delta C o m p \operatorname{Expd}(-1)$} & $0.106^{*}$ & 0.096 & 0.075 & & \\
\hline & $(0.065)$ & (0.069) & (0.059) & & \\
\hline \multirow[t]{2}{*}{ GrExpd(-1) } & & & & $0.159 * * *$ & $0.159 * * *$ \\
\hline & & & & $(0.044)$ & $(0.047)$ \\
\hline \multirow[t]{2}{*}{ DPol*Publicserv } & $1.122 * * *$ & $1.121 * * *$ & 0.236 & 4.351 & -1.728 \\
\hline & $(0.297)$ & $(0.297)$ & $(0.370)$ & (4.976) & (6.222) \\
\hline \multirow[t]{2}{*}{ DPol*Defence } & & -0.294 & & $-10.096 * *$ & -0.712 \\
\hline & & $(0.327)$ & & (4.083) & (4.953) \\
\hline \multirow[t]{2}{*}{ DPol*PublicOrder } & -0.322 & -0.321 & 0.252 & $-8.729 *$ & 4.204 \\
\hline & $(0.321)$ & $(0.397)$ & $(0.393)$ & (4.844) & $(4.036)$ \\
\hline \multirow[t]{2}{*}{ DPol*EconAffairs } & $-1.000 * * *$ & $-0.998 * * *$ & 0.053 & $-10.874 * *$ & -2.067 \\
\hline & $(0.390)$ & $(0.362)$ & $(0.313)$ & (4.287) & (5.716) \\
\hline \multirow[t]{2}{*}{ DPol*Environment } & 0.048 & & -0.017 & 3.698 & -4.880 \\
\hline & $(0.357)$ & & $(0.416)$ & $(4.826)$ & (4.433) \\
\hline \multirow[t]{2}{*}{ DPol*Amenities } & -0.237 & -0.238 & 0.295 & $-13.315^{* *}$ & $14.570 * *$ \\
\hline & $(0.364)$ & (0.371) & $(0.513)$ & $(5.435)$ & (7.039) \\
\hline \multirow[t]{2}{*}{ DPol*Health } & $0.510^{*}$ & $0.504^{*}$ & -0.494 & 2.726 & -6.079 \\
\hline & $(0.298)$ & $(0.303)$ & $(0.476)$ & (3.861) & $(5.411)$ \\
\hline \multirow[t]{2}{*}{ DPol*Recreation } & 0.164 & 0.163 & 0.027 & 5.181 & -1.780 \\
\hline & $(0.340)$ & $(0.345)$ & $(0.376)$ & (5.342) & (5.122) \\
\hline \multirow[t]{2}{*}{ DPol*Education } & 0.047 & 0.047 & 0.010 & -1.443 & -1.869 \\
\hline & (0.379) & $(0.386)$ & $(0.410)$ & (5.381) & $(4.287)$ \\
\hline No. Obs. & 180 & 180 & 180 & 210 & 210 \\
\hline
\end{tabular}

Notes: Standard-errors are in parentheses; significance level at which the null hypothesis is rejected: $* * *$, $1 \%$; * $5 \%$; and *, $10 \% . \Delta$ is the first difference operator. A bias-corrected least squares dummy variable estimator for dynamic panel data models is employed. The Blundell and Bond (1998) estimator is used as the initial estimator. We undertake 25 repetitions of the procedure to bootstrap the estimated standard errors. The results do not qualitatively change with more repetitions (50, 100 or 200) or when the Arellano and Bond (1991) estimator is chosen as initial estimator. 
Table 2. Election effects on the composition of government expenditures

\begin{tabular}{|c|c|c|c|c|c|c|c|c|c|c|}
\hline & PublicServ & Defence & PublicOrder & EconAffairs & Environment & Amenities & Health & Recreation & Education & SocialProtect \\
\hline \multirow[t]{2}{*}{ PublicServ } & -- & $1.414 * * *$ & $1.443 * * * *$ & $2.122 * * * *$ & $1.073 * *$ & $1.359 * * * *$ & 0.611 & $0.957 * *$ & $1.074 * *$ & $1.122 * * * *$ \\
\hline & -- & $(0.434)$ & (0.428) & $(0.487)$ & $(0.452)$ & $(0.407)$ & $(0.426)$ & $(0.416)$ & $(0.542)$ & $(0.297)$ \\
\hline \multirow[t]{2}{*}{ Defence } & $-1.414 * * * *$ & -- & 0.028 & 0.704 & -0.342 & -0.056 & $-0.798 *$ & -0.457 & -0.341 & -0.294 \\
\hline & $(0.434)$ & -- & $(0.491)$ & $(0.491)$ & $(0.529)$ & $(0.531)$ & $(0.425)$ & $(0.557)$ & $(0.521)$ & $(0.327)$ \\
\hline \multirow[t]{2}{*}{ PublicOrder } & $-1.443 * * * *$ & -0.028 & -- & 0.679 & -0.370 & -0.085 & $-0.832 * *$ & -0.486 & -0.369 & -0.322 \\
\hline & $(0.428)$ & $(0.491)$ & -- & $(0.485)$ & $(0.437)$ & $(0.523)$ & $(0.416)$ & $(0.548)$ & $(0.510)$ & $(0.321)$ \\
\hline \multirow[t]{2}{*}{ EconAffairs } & $-2.122 * * *$ & -0.704 & -0.679 & -- & $-1.049 *$ & -0.763 & $-1.511 * * *$ & $-1.165^{*}$ & $-1.048^{*}$ & $-1.000 * * *$ \\
\hline & $(0.487)$ & $(0.448)$ & $(0.485)$ & -- & $(0.612)$ & $(0.560)$ & $(0.421)$ & $(0.607)$ & $(0.514)$ & (0.390) \\
\hline \multirow[t]{2}{*}{ Environment } & $-1.073 * *$ & 0.342 & 0.370 & $1.049 *$ & -- & 0.285 & 0.462 & -0.116 & 0.001 & 0.048 \\
\hline & $(0.452)$ & $(0.529)$ & $(0.437)$ & $(0.612)$ & -- & $(0.536)$ & $(0.521)$ & $(0.487)$ & $(0.546)$ & $(0.357)$ \\
\hline \multirow[t]{2}{*}{ Amenities } & $-1.359 * * * *$ & 0.056 & 0.085 & 0.763 & -0.285 & -- & -0.747 & -0.401 & -0.284 & -0.237 \\
\hline & $(0.407)$ & $(0.531)$ & $(0.523)$ & $(0.560)$ & $(0.536)$ & -- & $(0.556)$ & $(0.379)$ & $(0.599)$ & $(0.365)$ \\
\hline \multirow[t]{2}{*}{ Health } & -0.611 & 0.798* & $0.832 * *$ & $1.511 * * *$ & 0.462 & 0.747 & -- & 0.346 & 0.463 & $0.511^{*}$ \\
\hline & $(0.426)$ & $(0.425)$ & $(0.416)$ & $(0.421)$ & $(0.521)$ & $(0.556)$ & -- & $(0.490)$ & $(0.395)$ & $(0.298)$ \\
\hline \multirow[t]{2}{*}{ Recreation } & $-0.957 * *$ & 0.457 & 0.486 & $1.165^{*}$ & 0.116 & 0.401 & -0.346 & -- & 0.117 & 0.164 \\
\hline & $(0.416)$ & $(0.557)$ & $(0.548)$ & $(0.607)$ & $(0.487)$ & $(0.379)$ & $(0.490)$ & -- & $(0.484)$ & $(0.340)$ \\
\hline \multirow[t]{2}{*}{ Education } & $-1.074 * *$ & 0.341 & 0.369 & $1.048 * *$ & -0.001 & 0.284 & -0.463 & -0.117 & -- & 0.047 \\
\hline & $(0.542)$ & $(0.521)$ & $(0.510)$ & $(0.514)$ & $(0.546)$ & $(0.599)$ & $(0.395)$ & $(0.484)$ & -- & $(0.379)$ \\
\hline \multirow[t]{2}{*}{ SocialProtect } & $-1.122 * * * *$ & 0.294 & 0.322 & $1.000 * * * *$ & -0.048 & 0.237 & $-0.511 *$ & -0.164 & -0.047 & -- \\
\hline & (0.297) & $(0.327)$ & $(0.321)$ & $(0.390)$ & $(0.357)$ & $(0.365)$ & $(0.298)$ & $(0.340)$ & $(0.379)$ & -- \\
\hline
\end{tabular}




\section{Annex}

\section{Table A.1 - The components of the government total expenditures}

General public services (PublicServ)

Executive and legislative organs; financial and fiscal affairs; external affairs; Foreign economic aid; General services; Basic research; R\&D general public services; Public debt transactions; Transfers of a general character between different levels of government; other General public services.

Defence (Defence)

Military defence; Civil defence; Foreign military aid; R\&D defence; other Defence expenditures.

Public order and safety (PublicOrder)

Police and Fire-protection; Law courts; Prisons; R\&D public order and safety; other Public order and safety expenditures.

\section{Economic affairs (EconAffairs)}

General economic, commercial and labour affairs; Agriculture; forestry; fishing and hunting;Fuel and energy; Mining; manufacturing and construction; Transport; Communication; R\&D economic affairs and other expenditures.

Environmental protection (Environment)

Waste management; Waste water management; Pollution abatement; Protection of biodiversity and landscape; R\&D environmental protection; other Environmental protection expenditures.

Housing and community amenities (Amenities)

Housing development; Community development; Water supply; Street lighting; R\&D housing and community amenities; other Housing and community amenities expenditures.

\section{Health (Health)}

Medical products, appliances and equipment; Outpatient services; Hospital services; Public health services; R\&D health; other Health expenditures.

\section{Recreation, culture and religion (Recreation)}

Recreational and sporting services; Cultural services; Broadcasting and publishing services; Religious and other community services; R\&D recreation, culture and religion; other Recreation, culture and religion expenditures.

\section{Education (Education)}

All education expenditures; Subsidiary services to education; R\&D education; other Education expenditures.

\section{Social protection (SocialProtect)}

Sickness and disability; Old age; Survivors; Family and children; Unemployment; Housing; Social exclusion; R\&D social protection; other Social protection expenditures.

Source: OECD (2009), Government at a Glance.

Table A.2 - Definition of the variables

CompExpd Government expenditures by component as percentage of the government total expenditures. The components of the total expenditures are specified in Table A.2.

GrExpd Growth rate of government expenditure by component, in percentage.

DPol Dummy for the political variables; it can either take the value of 1 for the electoral year (and 0 , otherwise) or the value of 1 for left-wing governments (and 0 , otherwise).

Sources: OECD Statistics from Government at a Glance.

Table A.3 - Descriptive Statistics

\begin{tabular}{lccccc}
\hline \multicolumn{1}{c}{ Variables } & Obs. & Mean & S.D. & Min. & Max. \\
\hline \hline CompExpd & 220 & 10.00 & 8.943 & 0.843 & 36.72 \\
GrExpd & 210 & 6.067 & 11.06 & -47.59 & 43.59 \\
DPol (Elect $=1)$ & 220 & 0.318 & 0.467 & 0.000 & 1.000 \\
DPol (LeftGov $=1)$ & 220 & 0.591 & 0.493 & 0.000 & 1.000 \\
\hline Sources: See Tab & & & & &
\end{tabular}

Sources: See Tables A.1 and A.2. 
Table A.4 - Unit root tests

\begin{tabular}{|c|c|c|c|c|c|c|c|c|c|c|}
\hline & \multirow[t]{2}{*}{ LLC } & \multirow[t]{2}{*}{ IPS } & \multicolumn{4}{|c|}{ Fisher-ADF } & \multicolumn{4}{|c|}{ Fisher-PP } \\
\hline & & & Inv. $\chi^{2}$ & Inv.N & Inv.L & M.Inv. $\chi^{2}$ & Inv. $\chi^{2}$ & Inv.N & Inv.L & M.Inv. $\chi^{2}$ \\
\hline CompExpd & 2757 & 0762 & 62.79 & -5.098 & -5.334 & & 19.72 & -0.238 & -0.246 & -0.045 \\
\hline & [0.003] & & {$[0.000]$} & {$[0.000]$} & {$[0.000]$} & {$[0.000]$} & [0.476] & {$[0.406]$} & [0.403] & {$[0.518]$} \\
\hline$\Delta$ СотрЕхрd & -4.542 & -4.999 & 110.9 & -8.177 & -9.738 & 14.38 & 163.0 & -10.59 & -14.33 & 22.61 \\
\hline & {$[0.000]$} & {$[0.000]$} & {$[0.000]$} & {$[0.000]$} & {$[0.000]$} & {$[0.000]$} & {$[0.000]$} & {$[0.000]$} & {$[0.000]$} & {$[0.000]$} \\
\hline GrExpd & $\begin{array}{c}-3.921 \\
{[0.000]}\end{array}$ & $\begin{array}{c}-4.600 \\
{[0.000]}\end{array}$ & $\begin{array}{c}106.1 \\
{[0.000]}\end{array}$ & $\begin{array}{c}-7.942 \\
{[0.000]}\end{array}$ & $\begin{array}{c}-9.304 \\
{[0.000]}\end{array}$ & $\begin{array}{c}13.61 \\
{[0.000]}\end{array}$ & $\begin{array}{c}115.0 \\
{[0.000]}\end{array}$ & $\begin{array}{l}-8.312 \\
{[0.000]}\end{array}$ & $\begin{array}{l}-10.06 \\
{[0.000]}\end{array}$ & $\begin{array}{c}15.02 \\
{[0.000]}\end{array}$ \\
\hline
\end{tabular}

Notes: For sources, see Tables A.1 and A.2. $\Delta$ is the first difference operator. For each test, we report the respective statistic and $p$-value (in square brackets). The Levin-Lin-Chu (LLC) and Im-Pesaran-Shin (IPS) unit root tests are performed over the panel with constant and one lag; the null hypothesis is that "all panels contain unit-roots". The LLC test assumes that all panels have the same autocorrelation coefficient, but the IPS test relaxes that assumption and allows each panel to have its own autocorrelation coefficient. The Fisher-type unit-root tests are based on augmented Dickey-Fuller (Fisher-ADF) tests and Phillips-Perron (Fisher-PP) tests with drift and one lag in all regressions; the null hypothesis is that "all panels contain unitroots"; these tests are conducted for each panel individually before combining the $p$-values from those tests to produce the overall test; the statistics and respective $p$-values (in square brackets) are reported for each type of Fisher test: inverse chi-squared, inverse normal, inverse logit and modified inverse chi-squared. 


\section{Most Recent Working Paper}

\begin{tabular}{|c|c|}
\hline $\begin{array}{l}\text { NIPE WP } \\
22 / 2014\end{array}$ & $\begin{array}{l}\text { Castro, Vítor e Rodrigo Martins, “ Are there political cycles hidden inside government } \\
\text { expenditures?”, } 2014\end{array}$ \\
\hline $\begin{array}{l}\text { NIPE WP } \\
21 / 2014\end{array}$ & $\begin{array}{l}\text { Conceição, Oscarina e Ana Paula Faria, "Determinants of research-based spin-offs survival”, } \\
2014\end{array}$ \\
\hline $\begin{array}{l}\text { NIPE WP } \\
20 / 2014\end{array}$ & $\begin{array}{l}\text { Conceição, Oscarina, Ana Paula Faria e Margarida Fontes, "Location of research-based spin- } \\
\text { offs: how relevant are regional effects?", } 2014\end{array}$ \\
\hline $\begin{array}{l}\text { NIPE WP } \\
19 / 2014\end{array}$ & $\begin{array}{l}\text { Sousa, Rita, Luís Aguiar-Conraria e Maria Joana Soares, "Carbon and Energy Prices: Surfing } \\
\text { the Wavelets of California", } 2014\end{array}$ \\
\hline $\begin{array}{l}\text { NIPE WP } \\
18 / 2014\end{array}$ & $\begin{array}{l}\text { Aguiar-Conraria, Luís, Manuel M. F. Martins e Maria Joana Soares, “Analyzing the Taylor } \\
\text { Rule with Wavelet Lenses”, } 2014\end{array}$ \\
\hline $\begin{array}{l}\text { NIPE WP } \\
17 / 2014\end{array}$ & $\begin{array}{l}\text { Veiga, Linda Gonçalves, "Descentralização orçamental: questões de autonomia e } \\
\text { responsabilização", } 2014\end{array}$ \\
\hline $\begin{array}{l}\text { NIPE WP } \\
16 / 2014\end{array}$ & $\begin{array}{l}\text { Veiga, Linda Gonçalves e Francisco José Veiga, "Determinants of Portuguese local } \\
\text { governments' indebtedness", } 2014\end{array}$ \\
\hline $\begin{array}{l}\text { NIPE WP } \\
15 / 2014\end{array}$ & $\begin{array}{l}\text { Baleiras, Rui Nuno, "Em prol da previsibilidade e da sustentabilidade das finanças públicas: um } \\
\text { comentário a "Controlo da Execução Orçamental no Estado", } 2014\end{array}$ \\
\hline $\begin{array}{l}\text { NIPE WP } \\
14 / 2014\end{array}$ & $\begin{array}{l}\text { Bernardino, Susana e J. Freitas Santos "Implicações do contexto político-legal para o } \\
\text { lançamento de novas iniciativas sociais em Portugal”, } 2014\end{array}$ \\
\hline $\begin{array}{l}\text { NIPE WP } \\
13 / 2014 \\
\end{array}$ & $\begin{array}{l}\text { Lebre de Freitas, Miguel “ On inflation and money demand in a portfolio model with shopping } \\
\text { costs ", } 2014\end{array}$ \\
\hline $\begin{array}{l}\text { NIPE WP } \\
12 / 2014\end{array}$ & $\begin{array}{l}\text { Lebre de Freitas, Miguel e Miguel de Faria e Castro "The Portuguese real exchange rate, 1995- } \\
\text { 2010: competitiveness or price effects", } 2014\end{array}$ \\
\hline $\begin{array}{l}\text { NIPE WP } \\
11 / 2014\end{array}$ & $\begin{array}{l}\text { Morozumi, Atsuyoshi e Veiga, Francisco José, "Public spending and growth: the role of } \\
\text { institutions", } 2014\end{array}$ \\
\hline $\begin{array}{l}\text { NIPE WP } \\
10 / 2014\end{array}$ & $\begin{array}{l}\text { Brekke, Kurt R., Siciliani, Luigi e Straume, Odd Rune, "Hospital Mergers with Regulated } \\
\text { Prices", } 2014\end{array}$ \\
\hline $\begin{array}{l}\text { NIPE WP } \\
09 / 2014\end{array}$ & Esteves, Rosa-Branca, “Behavior-Based Price Discrimination with Retention Offers”, 2014 \\
\hline $\begin{array}{l}\text { NIPE WP } \\
08 / 2014\end{array}$ & $\begin{array}{l}\text { Esteves, Rosa-Branca e Sofia Cerqueira, "Behaviour-Based Price Discrimination under } \\
\text { Advertising and Imperfectly Informed Consumers", } 2014\end{array}$ \\
\hline $\begin{array}{l}\text { NIPE WP } \\
07 / 2014\end{array}$ & Brekke, K.R., Siciliani, L. e Odd Rune Straume, "Horizontal Mergers and Product Quality”, 2014 \\
\hline $\begin{array}{l}\text { NIPE WP } \\
06 / 2014\end{array}$ & $\begin{array}{l}\text { Hammoudeh, S., Nguyen, Duc K. e Ricardo M. Sousa, "Energy prices and CO2 emission } \\
\text { allowance prices: A quantile regression approach",2014 }\end{array}$ \\
\hline $\begin{array}{l}\text { NIPE WP } \\
05 / 2014\end{array}$ & $\begin{array}{l}\text { Hammoudeh, S., Lahiani, A., Nguyen, Duc, K. e Ricardo M. Sousa, "Asymmetric and nonlinear } \\
\text { pass-through of energy prices to CO2 emission allowance prices", } 2014\end{array}$ \\
\hline $\begin{array}{l}\text { NIPE WP } \\
04 / 2014 \\
\end{array}$ & $\begin{array}{l}\text { Hammoudeh, S., Nguyen, Duc K. e Ricardo M. Sousa, "What explains the short-term dynamics } \\
\text { of the prices of CO2 emissions?", } 2014\end{array}$ \\
\hline $\begin{array}{l}\text { NIPE WP } \\
03 / 2014\end{array}$ & $\begin{array}{l}\text { Sousa, Rita, Aguiar- Conraria e Maria Joana Soares, "Carbon Financial Markets: a time- } \\
\text { frequency analysis of CO2 price drivers", } 2014\end{array}$ \\
\hline $\begin{array}{l}\text { NIPE WP } \\
02 / 2014\end{array}$ & Sousa, Rita e Luís Aguiar-Conraria, “Dynamics of CO2 price drivers”, 2014 \\
\hline $\begin{array}{l}\text { NIPE WP } \\
01 / 2014 \\
\end{array}$ & $\begin{array}{l}\text { Brekke, Kurt R., Holmäs, Tor Helge e Straume, Odd Rune, "Price Regulation and Parallel } \\
\text { Imports of Pharmaceuticals", } 2014\end{array}$ \\
\hline $\begin{array}{l}\text { NIPE WP } \\
22 / 2013\end{array}$ & $\begin{array}{l}\text { Leal, Cristiana Cerqueira, Armada, Manuel Rocha e Loureiro, Gilberto , "Individual } \\
\text { Investors Repurchasing Behavior: Preference for Stocks Previously Owned", } 2013\end{array}$ \\
\hline $\begin{array}{l}\text { NIPE WP } \\
21 / 2013 \\
\end{array}$ & $\begin{array}{l}\text { Loureiro, Gilberto e Alvaro G. Taboada, "Equity Offerings Abroad and the adoption of IFRS: A } \\
\text { test of the Capital Markets Liability of Foreignness", } 2013\end{array}$ \\
\hline $\begin{array}{l}\text { NIPE WP } \\
20 / 2013 \\
\end{array}$ & $\begin{array}{l}\text { Loureiro, Gilberto e Alvaro G. Taboada, "Do Improvements in the Information Environment } \\
\text { Affect Real Investment Decisions?", } 2013\end{array}$ \\
\hline
\end{tabular}

